\title{
Kompetencja kluczowa czy przedmiot szkolny? Nauczanie przedsiębiorczości w szkołach w Europie
}

DOI: $10.47050 / 65591760.284-300$

Magdalena Górowska-Fells, Beata Płatos

Tekst jest poświęcony tematyce nauczania przedsiębiorczości jako jednej z kompetencji kluczowych w szkołach w Europie. Informuje o sposobach włączania treści o tematyce dotyczącej przedsiębiorczości do programów szkolnych na poziomie szkoły podstawowej i średniej - zarówno pierwszego, jak i drugiego stopnia. Omawia również stosowane narzędzia dydaktyczne oraz metody nauczania, w tym uczenie się poprzez zaangażowanie w działania firm/przedsiębiorstw szkolnych. Analizą objęto nauczanie realizowane w ramach zajęć obowiązkowych, zajęć dodatkowych i projektów szkolnych oraz pozaszkolnych.

\author{
Słowa kluczowe: \\ przedsiębiorczość \\ kompetencje kluczowe \\ efekty kształcenia \\ program szkolny \\ przedmiot szkolny \\ metody nauczania \\ narzędzia dydaktyczne \\ zajęcia pozalekcyjne \\ przedsiębiorstwo szkolne
}




\section{Key competence or school subject? Entrepreneurship education in schools in Hurope}

DOI: $10.47050 / 65591760.284-300$

Magdalena Górowska-Fells, Beata Płatos

The article is devoted to the topic of teaching entrepreneurship at school in Europe as one of the key competences. It presents ways of including entrepreneurship in the school programmes at the level of primary and both lower and upper secondary education. It informs about didactic tools and teaching methods used at school including learning through involvement in school enterprises. Entrepreneurship is discussed as implemented during both compulsory and extracurricular classes, as well as projects implemented at school and outside.

\section{Keywords:}

entrepreneurship

key competences

learning outcomes

school programme

school subject

teaching methods

didactic tools

extracurricular classes

school enterprise 


\section{Wstęp}

Przedsiębiorczość, jako jedna z kompetencji kluczowych, jest od kilku lat systematycznie włączana do programów szkolnych w większości krajów Europy. Proces ten jest szczegółowo analizowany przez sieć Eurydice, która opublikowała dwa raporty dotyczące nauczania przedsiębiorczości w szkołach w Europie - w latach 2012 i 2016 - oraz planuje opracowanie kolejnego (w roku 2019). W raporcie Eurydice z roku 2016 można prześledzić, jak poszczególne kraje (w sumie 33) realizują nauczanie przedsiębiorczości. Analizę przeprowadzono na podstawie zapisów w legislacji krajowej, a nie na podstawie badań prowadzonych w szkołach, ale możemy założyć, że szkoły korzystają z zaleceń dotyczących zarówno treści (odpowiednik polskiej podstawy programowej), jak i metod dydaktycznych, gdyż przeważnie są później z tego rozliczane. Celem niniejszego tekstu jest przedstawienie, na podstawie analizy dostępnych raportów, jak przedsiębiorczość wpisuje się w programy szkolne w Europie i jak kształtowane są związane z nią kompetencje.

\section{Włączanie przedsiębiorczości do programów szkolnych}

Większość krajowych definicji przedsiębiorczości stosowanych w krajowych dokumentach strategicznych dotyczących edukacji i w programach szkolnych jest spójna z europejską definicją kompetencji kluczowych. Większość z tych definicji ma szeroki charakter odnoszący się nie tylko do rynku pracy i działalności gospodarczej, lecz także do ogólnego kontekstu funkcjonowania jednostki w życiu społecznym (zob. Borowiec-Gabryś, Kilar, Rachwał 2018; Rachwał i in. 2018; Wach 2013).

Przedsiębiorczość jest włączana w Europie do szkolnych programów nauczania na różne sposoby. Nauczanie jej może się odbywać w ramach odrębnego przedmiotu lub może być zintegrowane z innymi przedmiotami. Może być ono uwzględnione w programie szkolnym jako obowiązkowe lub fakultatywne. Wiele ciekawych działań jest realizowanych w ramach zajęć dodatkowych, pozalekcyjnych czy inicjatyw i projektów prowadzonych przez instytucje współpracujące ze szkołami (Eurydice 2016).

Treści dotyczące przedsiębiorczości w programach nauczania są najczęściej realizowane w ramach:

$\rightarrow$ międzyprzedmiotowych celów kształcenia - cele dotyczące przedsiębiorczości są wpisane w ogólne cele kształcenia i/lub wplecione w treści szczegółowe kilku/wielu przedmiotów, 
$\rightarrow$ odrębnego obowiązkowego przedmiotu szkolnego (lub przedmiotów) poświęconego wyłącznie nauczaniu przedsiębiorczości,

$\rightarrow$ odrębnego przedmiotu fakultatywnego (lub przedmiotów) poświęconego wyłącznie nauczaniu przedsiębiorczości.

Podejścia nie wykluczają się i mogą w poszczególnych krajach występować równolegle (Eurydice 2016).

\section{Szkolnictwo podstawowe i średnie pierwszego stopnia}

Z raportu Komisji Europejskiej wynika, że najczęściej edukację w zakresie przedsiębiorczości zaczyna się od pojedynczych treści lub ogólnych celów kształcenia w młodszym wieku (np. w szkole podstawowej), a następnie treści dotyczące przedsiębiorczości są rozbudowywane na poziomie szkolnictwa średniego jako obowiązkowa, integralna część programu nauczania (McCoshan, za: Eurydice 2016).

Z raportu Eurydice z 2016 r. wynika, że prawie połowa krajów stosuje w szkolnictwie podstawowym podejście międzyprzedmiotowe, nie wiążąc celów ani treści nauczania przedsiębiorczości z konkretnymi przedmiotami. W Estonii, gdzie realizowana jest strategia na rzecz popularyzacji nauczania przedsiębiorczości w szkolnictwie podstawowym, kompetencja "bycia przedsiębiorczym" (umiejętność działania w sposób przedsiębiorczy) powinna być rozwijana w trakcie całego procesu kształcenia. Oprócz celów interdyscyplinarnych funkcjonuje tam również ścieżka międzyprzedmiotowa - inicjatywa obywatelska i przedsiębiorczość. Kształcenie kompetencji przedsiębiorczych jest realizowane $w$ ramach wszystkich obszarów nauczania na poziomie szkoły podstawowej także w Hiszpanii i Słowenii. Cztery kraje (Czechy, Łotwa, Malta i Rumunia) stosują wszystkie trzy podejścia - łączą cele międzyprzedmiotowe z obowiązkową nauką przedsiębiorczości oraz oferują przedmioty do wyboru.

W kilku systemach w szkolnictwie podstawowym treści dotyczące przedsiębiorczości znalazły się w programach nauczania przedmiotów obowiązkowych, np. w Austrii i na Słowacji. Natomiast przedmioty do wyboru są w szkolnictwie podstawowym rzadko spotykane i w związku z tym przedmiot fakultatywny uwzględniający przedsiębiorczość występuje bardzo rzadko.

Z kolei w szkolnictwie średnim pierwszego stopnia, częściej niż w podstawowym, łączy się różne podejścia - osiem krajów łączy wszystkie trzy opcje. Najczęściej (w 17 krajach) obserwowane jest 
obowiązkowe nauczanie przedsiębiorczości jako oddzielnego przedmiotu lub w ramach innego przedmiotu/przedmiotów, znacznie częściej niż w szkolnictwie podstawowym. Także występowanie treści nauczania dotyczących przedsiębiorczości jako przedmiotu do wyboru jest bardziej powszechne niż w szkolnictwie podstawowym. Tylko osiem krajów nie włączyło w żaden sposób treści związanych z przedsiębiorczością do programów nauczania (Eurydice 2016).

W szkolnictwie podstawowym i średnim pierwszego stopnia przedsiębiorczość jest odrębnym obowiązkowym przedmiotem tylko w czterech krajach. Pozostałe włączają treści dotyczące przedsiębiorczości do takich przedmiotów jak nauki społeczne i ekonomiczne, poradnictwo zawodowe, matematyka, przedmioty ścisłe, technika, TIK, a nawet sztuka, muzyka, języki obce, rozwój osobisty oraz etyka. Nauczanie przedsiębiorczości jest najczęściej zintegrowane z przedmiotami w dziedzinie nauk społecznych oraz ekonomii. W Polsce w dotychczasowym systemie sześcioletniej szkoły podstawowej i trzyletniego gimnazjum była ona włączona głównie w przedmiot wiedza o społeczeństwie na poziomie gimnazjalnym (Rachwał, Kurek, Boguś 2016).

\section{Szkolnictwo średnie drugiego stopnia}

\section{- ogólnokształcące i zawodowe}

Nauczanie przedsiębiorczości jest bardziej rozpowszechnione w szkołach średnich drugiego stopnia niż w szkolnictwie podstawowym i średnim pierwszego stopnia. Na tym poziomie znacznie częściej szkoły mają za zadanie realizowanie treści dotyczących przedsiębiorczości jako celu międzyprzedmiotowego (20 krajów), również częściej spotykane jest łączenie wszystkich trzech podejść (cel międzyprzedmiotowy, przedmiot obowiązkowy oraz przedmioty do wyboru). Nauka przedsiębiorczości jest obowiązkowa w 18 krajach, a jedynie w pięciu w ogóle jej się nie uwzględnia w programach. Realizacja najczęściej polega na wyodrębnieniu osobnego przedmiotu (dotyczy to połowy krajów), częściej w formie fakultatywnej niż obowiązkowej. Taki model prowadzony jest w Polsce, gdzie we wszystkich szkołach średnich (ogólnokształcących i zawodowych) realizowany jest obowiązkowy przedmiot podstawy przedsiębiorczości (Rachwał i in. 2018).

Również w szkolnictwie zawodowym przedsiębiorczość to najczęściej oddzielny przedmiot, równie często obowiązkowy, co do wyboru (odpowiednio dziewięć i 10 krajów). Tam, gdzie nie ustanowiono 
odrębnego przedmiotu, przedsiębiorczość jest najczęściej nauczana w ramach nauk społeczno-ekonomicznych. Ciekawy jest przypadek Holandii, gdzie szkoły mają dużą autonomię w dziedzinie doboru treści nauczania, w tym przedsiębiorczości. Przeważnie realizują projekty i wprowadzają treści dotyczące przedsiębiorczości do swoich programów nauczania (na wszystkich poziomach szkolnictwa), mimo że nie mają takiego obowiązku.

Podsumowując: nauczanie przedsiębiorczości jest stopniowo wprowadzane w szkołach podstawowych i średnich pierwszego stopnia, często jako ścieżka międzyprzedmiotowa, a pełna realizacja celów nauczania następuje w szkołach średnich drugiego stopnia.

\section{Efekty kształcenia w dziedzinie przedsiębiorczości}

Analiza treści nauczanych w ramach przedmiotu czy przedmiotów uwzględniających problematykę przedsiębiorczości pozwala na dostrzeżenie pewnego charakterystycznego zjawiska. W podstawach programowych nie mówi się obecnie o treściach nauczania ani wiedzy, którą należy przekazać. Podstawy programowe (w tym polska) są sformułowane w języku efektów kształcenia. Jeśli chcemy się dowiedzieć, jakich treści naucza się w szkołach, to musimy zapoznać się z opisem wyników tego kształcenia, czyli tego, co uczeń będzie potrafił po skończeniu edukacji.

Na potrzeby analiz prowadzonych przez Eurydice wyróżniono trzy kategorie efektów kształcenia występujące w europejskich programach nauczania przedsiębiorczości. Są to:

$\rightarrow$ postawy (pewność siebie i inicjatywność),

$\rightarrow$ umiejętności (kreatywne rozwiązywanie problemów, planowanie, stosowanie wiedzy z zakresu finansów, organizowanie zasobów, zarządzanie ryzykiem oraz praca zespołowa),

$\rightarrow$ wiedza (ocena warunków do działalności gospodarczej, rola przedsiębiorców w społeczeństwie i ścieżki kariery w biznesie).

Wprowadzenie powyższych kategorii ułatwiło przeprowadzenie porównań międzykrajowych. W szkolnictwie podstawowym i średnim pierwszego stopnia odnotowano częste występowanie efektów kształcenia odnoszących się do postaw przedsiębiorczych oraz umiejętności takich jak: kreatywne rozwiązywanie problemów, planowanie, stosowanie wiedzy z zakresu finansów i praca zespołowa oraz w kategorii 
wiedza - roli przedsiębiorców w społeczeństwie. Pozostałe kategorie występowały rzadko, zdecydowanie najrzadziej występującym efektem kształcenia w kategorii umiejętności było organizowanie zasobów i zarządzanie ryzykiem, w kategorii wiedzy - ocena warunków do działalności gospodarczej oraz ścieżki kariery w przedsiębiorczości. Badania nad polską podstawą programową wskazywały na dominację kategorii efektów kształcenia związanych bardziej z wiedzą ekonomiczną niż kształtowaniem umiejętności i postaw przedsiębiorczych. Dlatego w nowej podstawie programowej położono większy nacisk na kształtowanie postaw, stosowanie wiedzy w praktyce i rozwój umiejętności związanych z przedsiębiorczością (Rachwał, Kurek, Boguś 2016; Rachwał i in. 2018).

Z kolei w szkolnictwie średnim drugiego stopnia i w szkołach zawodowych występowanie poszczególnych kategorii efektów kształcenia jest zbliżone do tego na niższych poziomach - podobieństwo to dotyczy aż 20 krajów. Różnice są niewielkie i związane np. z występowaniem pracy zespołowej, która nieco częściej jest wymieniana dla poziomów niższych. Największe różnice dotyczą efektów kształcenia związanych z umiejętnościami, które rzadko występowały na niższych szczeblach kształcenia, czyli z organizowaniem zasobów, zarządzaniem ryzykiem czy w kategorii wiedza - oceną warunków do działalności gospodarczej, czyli czy dany pomysł biznesowy uda się z sukcesem zrealizować w konkretnych warunkach. Występują one znacznie częściej w programach dla szkół średnich drugiego stopnia oraz zawodowych niż na niższych poziomach kształcenia. Wynika to z różnego stopnia dojrzałości uczniów na różnych poziomach edukacji i konieczności dostosowania efektów kształcenia do ich wieku.

Ciekawe jest zjawisko określania wielu różnych efektów kształcenia przez niektóre kraje (np. Estonia, Hiszpania, Rumunia, Finlandia, Słowenia, a także Polska), co według autorów raportu służy ciągłości i progresji między wszystkimi poziomami edukacji. Niestety, z raportu wynika, że progresja uzyskana w niektórych kategoriach efektów kształcenia często nie występuje w pozostałych kategoriach. Programy nauczania zawierają elementy przedsiębiorczości, ale efekty kształcenia nie są wystarczająco uporządkowane i zaplanowane, aby zapewnić ich kontynuację w ramach uczenia się przez całe życie. Gdy przedsiębiorczość jest nauczana jako ścieżka międzyprzedmiotowa, powiązania między przedmiotami uwzględniającymi treści z zakresu 
przedsiębiorczości są jeszcze bardziej ograniczone i trudno o połączenie efektów kształcenia w jedno spójne doświadczenie edukacyjne (Eurydice 2016).

Pozytywne przykłady udanej progresji kształcenia dotyczą głównie krajów, w których zadbano o opracowanie długofalowych programów w podziale na różne poziomy nauczania. W Norwegii przedmiot przedsiębiorczość i rozwijanie działalności gospodarczej bazuje na progresywnym budowaniu umiejętności od opisu procesu opracowywania produktu (klasa pierwsza szkoły średniej drugiego stopnia) do dalszego rozwoju pomysłu biznesowego w klasie drugiej. Podobne przykłady progresji można też wskazać w Wielkiej Brytanii (Szkocja), gdzie cel polegający na „zapoznaniu się z narzędziami, które pobudzają przedsiębiorczość i oddziałują na gospodarkę" jest realizowany aż na pięciu poziomach kształcenia (Eurydice 2016).

Warto przypomnieć, że nie wszystkie kraje prowadzą obowiązkową edukację w zakresie przedsiębiorczości i część analizowanych efektów kształcenia nie jest dostępna dla wszystkich uczniów, ale tylko dla tych, którzy wybrali przedmiot (lub przedmioty) obejmujący swym zakresem przedsiębiorczość.

\section{Narzędzia dydaktyczne stosowane w edukacji w zakresie przedsiębiorczości}

\section{Programy szkolne i metody nauczania}

Raport Eurydice podkreśla, że skuteczne nauczanie przedsiębiorczości nie jest możliwe za pomocą tradycyjnych metod dydaktycznych (Eurydice 2016). W tej sytuacji szczególnie ważne jest umożliwienie uczniom podejmowania działań praktycznych o charakterze przedsiębiorczym, a tradycyjne szkoły nie są do końca przygotowane na wyzwania tego typu. Dotyczy to również nauczycieli, którzy rzadko mają doświadczenia z własnej działalności gospodarczej (Sawiński 2011) i przygotowanie ich do roli nauczyciela przedsiębiorczości może stanowić bardzo trudne zadanie.

Warto podkreślić, że wiele krajów, w tym Polska, pozostawia szkołom i nauczycielom znaczną autonomię w wyborze metod nauczania. W ponad połowie krajów obowiązuje niewiele zaleceń dotyczących metod nauczania przedsiębiorczości lub występuje zupełny ich brak. Wytyczne dla szkół pod- 
stawowych i średnich opracowano zaledwie w 12 systemach edukacji, a w pięciu nauczanie odbywa się na podstawie odrębnych strategii skoncentrowanych na temacie przedsiębiorczości (we Wspólnocie Niemieckojęzycznej Belgii, w Estonii, Bośni i Hercegowinie, Czarnogórze i Macedonii). Estońska strategia nauczania przedsiębiorczości "Bądź przedsiębiorczy!" zawiera zalecenia dotyczące dydaktyki. Wytyczne dotyczące metod są najczęściej formułowane dla szkół średnich drugiego stopnia, gdyż na tym poziomie najczęściej naucza się przedsiębiorczości. Takie ogólne wytyczne znajdują się w polskiej podstawie programowej do przedmiotu podstawy przedsiębiorczości w części zatytułowanej „Warunki i sposób realizacji” (Rachwał i in. 2018), niemniej w Polsce przyjmuje się, że szczegóły dotyczące stosowanych metod formułowane są w szkolnych programach nauczania, które są bardziej szczegółowe niż podstawa programowa i dostosowane do lokalnych uwarunkowań. Najczęściej takie szczegółowe wytyczne formułowane są przez autorów poradników metodycznych dla nauczycieli (zob. Makieła, Rachwał 2002).

Raport Eurydice wskazuje, że w Europie wyróżnia się cztery rodzaje metod dydaktycznych najczęściej pojawiających się w zaleceniach krajowych stosowanych w nauczaniu przedsiębiorczości:

$\rightarrow$ metody aktywizujące,

$\rightarrow$ praca w projektach/projekty szkolne,

$\rightarrow$ uczenie się poprzez doświadczenie,

$\rightarrow$ zajęcia pozaszkolne prowadzone we współpracy ze społecznością lokalną i z przedsiębiorstwami (Eurydice 2016).

Najbardziej rozpowszechnione metody to te aktywizujące uczniów, np. poprzez wizyty w przedsiębiorstwach (Łotwa, Austria, Serbia). Wprowadza się je także obecnie do nowej podstawy programowej w Polsce (Rachwał i in. 2018). Jednak z punktu widzenia Komisji Europejskiej najbardziej pożądane metody pozwalają uczniom na zgromadzenie doświadczeń praktycznych w dziedzinie przedsiębiorczości i kształtują postawy przedsiębiorcze. Raport Eurydice, nawiązując do wezwania Komisji Europejskiej, aby państwa członkowskie zapewniły uczniom przynajmniej jedno doświadczenie praktyczne w dziedzinie przedsiębiorczości w ramach kształcenia obowiązkowego, przedstawia kilka najważniejszych modeli zaobserwowanych w europejskich programach nauczania (Komunikat KE 2012). Są to: 
$\rightarrow$ praca w projektach (w dziedzinie przedsiębiorczości),

$\rightarrow$ wyzwania praktyczne i społeczne - rozwiązanie konkretnych problemów w środowisku pracy wskazanych przez przedsiębiorców lub instytucje z zewnątrz czy rozwiązanie konkretnych problemów występujących w środowisku lokalnym,

$\rightarrow$ tworzenie miniprzedsiębiorstw - założenie i prowadzenie przez pewien czas przedsiębiorstwa przez uczniów,

$\rightarrow$ uczniowskie inicjatywy mikrofinansowania - pomysły i projekty typu crowdfunding, nastawione na osiągnięcie zysku.

Zdobycie praktycznego doświadczenia w zakresie przedsiębiorczości poprzez pracę w projektach jest najbardziej rozpowszechnionym modelem, a mimo to jest uwzględnione w szkolnych programach nauczania tylko kilkunastu krajów (mniej niż jedna trzecia badanych systemów edukacji). Praca w projektach dotyczących przedsiębiorczości rzadko jest realizowana na wszystkich trzech poziomach kształcenia (tylko w trzech krajach: Bułgaria, Bośnia i Hercegowina oraz Czarnogóra). W Danii projekty dotyczące przedsiębiorczości są realizowane wyłącznie w ramach szkolnictwa zawodowego. Warto więc przyjrzeć się bliżej kilku krajom, które ten typ kształcenia zapewniają. I tak w Finlandii działa projekt "Ja i moje miasto", w ramach którego w symulacji miniaturowego miasta uczniowie (12-13 lat) pracują w określonych zawodach i wypełniają obowiązki obywatelskie. Uczestnictwo w projekcie nie jest obowiązkowe, ale w zasadzie wszyscy uczniowie klas szóstych biorą w nim udział. W Norwegii uczniowie w tym samym wieku mają z kolei możliwość wyboru spośród przedmiotów fakultatywnych, które obejmują m.in. praktyczne działania przedsiębiorcze. W ramach przedmiotu umiejętności potrzebne w pracy zawodowej uczniowie tworzą konkretny produkt (Eurydice 2016).

Drugim najbardziej rozpowszechnionym sposobem zdobycia doświadczenia w zakresie przedsiębiorczości jest tworzenie miniprzedsiębiorstw lub przedsiębiorstw młodzieżowych. Praktyki tego typu są prowadzone zwykle z udziałem starszych uczniów, a w szkołach podstawowych stosuje się je jedynie w Hiszpanii. W szkołach średnich drugiego stopnia możliwość organizowania przedsiębiorstw uczniowskich jest przewidziana w 16 krajach. Tworzenie miniprzedsiębiorstw odbywa się często poprzez współpracę z instytucjami, które specjalizują się w tego typu działaniach, np. w Danii - Duńska Fundacja Przedsiębior- 
czości. W kilku krajach praktyki w postaci działających firm uczniowskich są bardzo popularne. W Finlandii w roku szkolnym 2013/2014 powstało 1,3 tys. przedsiębiorstw młodzieżowych, w których przeszkolono ponad 4 tys. uczniów. W kolejnym roku szkolnym 20 proc. szwedzkich uczniów wzięło udział w podobnych działaniach w ramach programu "Firma", a w Estonii działały 42 miniprzedsiębiorstwa w szkołach średnich pierwszego stopnia oraz 200 w szkołach średnich drugiego stopnia. W Austrii w szkolnictwie zawodowym działa ponad tysiąc tego typu firm. W Polsce ta idea realizowana jest fakultatywnie przez szkoły, głównie w ramach programu edukacyjnego Fundacji Młodzieżowej Przedsiębiorczości.

W Holandii, gdzie obowiązuje autonomia programowa, niektóre szkoły specjalizują się i określają jako enterprenasium, co oznacza placówkę, w której uczniowie mogą prowadzić własne przedsiębiorstwo, albo jako technasium, czyli szkołę łączącą technologię z innowacyjną przedsiębiorczością, często poprzez współpracę z klientami zewnętrznymi. Przedsiębiorstwo młodzieżowe działa przez określony czas, najczęściej jeden rok szkolny. Jest prowadzone zgodnie z obowiązującymi zasadami rynkowymi, regulującymi podstawowe kwestie finansowe i organizacyjne, oraz zasadami dotyczącymi wydajności i opłacalności działań. Uczniowie realizują wszystkie podstawowe czynności w firmie, są odpowiedzialni za zakupy, sprzedaż, promocję, fakturowanie, księgowość itp. Miniprzedsiębiorstwo nie posiada faktycznej osobowości prawnej, ale może być prowadzone na zasadzie różnych form prawnych i przybierać różne modele organizacyjne.

Uczniowie prowadzą działalność gospodarczą najczęściej nieodpłatnie, choć w przypadku niektórych krajów mogą otrzymywać niewysokie wynagrodzenie, w zależności od modelu organizacyjnego przedsiębiorstwa i poczynionych uzgodnień, np. ustalonej kwoty, której sprzedaż i wypracowane zyski nie mogą przekroczyć (w przeciwnym wypadku stosuje się przepisy podatkowe). Z kolei pracownicy szkoły w przypadku niektórych krajów mogą otrzymywać dodatkowe wynagrodzenie za taką działalność (zgodnie z odpowiednimi przepisami, np. we Włoszech to krajowe układy zbiorowe i przepisy regulujące łączenie urzędów), jednak według częściej występującego modelu nie mogą być zatrudniani w przedsiębiorstwach uczniowskich, a praca z uczniami w tego typu projektach nie wiąże się ze zmniejszeniem ich pensum dydaktycznego. 
Wyzwania praktyczne i społeczne oraz uczniowskie inicjatywy mikrofinansowania są w programach nauczania na razie zjawiskiem rzadkim (Eurydice 2016). Jedyny przykład inicjatywy mikrofinansowania znaleziono w Austrii - jest to program „Innowacyjna młodzież" (Jugend Innovativ).

\section{Programy realizowane po lekcjach i poza szkołą}

Europejscy uczniowie gromadzą również praktyczne umiejętności w dziedzinie przedsiębiorczości w trakcie zajęć pozalekcyjnych oraz działań organizowanych przez instytucje spoza szkoły. Kontakt z rzeczywistością pozaszkolną to jeden ze sposobów kształtowania postaw przedsiębiorczych wśród uczniów.

Z raportu Eurydice (2016) wynika, że ważną rolę w tej dziedzinie odgrywa międzynarodowa organizacja pozarządowa Junior Achievement oraz jej organizacje członkowskie w poszczególnych krajach (w Polsce pod nazwą Fundacja Młodzieżowej Przedsiębiorczości). W niektórych krajach organizacja pozyskała akredytację ministerstwa edukacji (w Polsce, a także w Czechach, Norwegii, Szwecji i Serbii) lub otrzymuje na swoje działania dotacje rządowe (Eurydice 2016). Z kolei we Wspólnocie Flamandzkiej Belgii, Bułgarii, Estonii, Grecji i na Łotwie programy opracowane przez Junior Achievement są realizowane w ramach standardowych programów nauczania (Eurydice, 2016). W Estonii Fundacja Enterprise Estonia corocznie organizuje konkurs wniosków na projekty dotyczące rozwijania postaw przedsiębiorczych wśród młodzieży. W Wielkiej Brytanii działają organizacje charytatywne, np. MyBank, który uczy młodych ludzi, jak należy zarządzać swoimi pieniędzmi i zakładać własne firmy, oraz Young Enterprise, która proponuje młodzieży udział w programach umożliwiających im poznanie świata biznesu i pracy zawodowej.

W ramach zajęć pozalekcyjnych są też organizowane konkursy związane z przedsiębiorczością, np. austriacki konkurs "Następne pokolenie", w którym uczniowie szkół zawodowych konsultują swoje pomysły biznesowe z trenerami biznesu, czy brytyjski konkurs "Tycoons in Schools", umożliwiający uczniom założenie i prowadzenie działalności gospodarczej. Praktyczne zajęcia dodatkowe są często inicjowane na szczeblu regionalnym (np. w Hiszpanii) lub lokalnym (Eurydice 2016).

Wiele programów tego typu jest realizowanych w krajach europejskich w ramach programu Erasmus+. Przykładowo w konsorcjum 
partnerów z Węgier, Niemiec i Polski wypracowano program rozwoju 10 kompetencji przedsiębiorczych w ramach zajęć pozalekcyjnych (Kilar i in. 2016). Jak wskazała faza pilotażowa realizacji programu, jego wdrożenie może przyczynić się do lepszego rozwoju postaw przedsiębiorczych młodzieży, szczególnie tej zagrożonej bezrobociem i niepodejmującej dalszej edukacji (Kilar i in. 2017).

Niestety, nadal w bardzo niewielu krajach doświadczenie praktyczne w zakresie przedsiębiorczości stanowi stały i obowiązkowy element programu nauczania. Nowa podstawa programowa kształcenia ogólnego w Polsce, zawierająca takie doświadczenia praktyczne jak np. ćwiczenia terenowe w przedsiębiorstwach, nie tylko w ramach przedmiotu podstawy przedsiębiorczości, lecz także geografii, jako integralny element procesu kształcenia, daje szansę na poprawę w tym zakresie (Rachwał i in. 2018).

\section{Podsumowanie}

Dane Eurobarometru z 2014 r. pokazują, że większość młodych ludzi w UE (w wieku 15-29 lat) nie chce uruchamiać własnej działalności gospodarczej, a ponad 20 proc. chciałoby, ale uważa to za zbyt trudne (Eurobarometr 2014, cyt. za Eurydice 2016). W tej sytuacji wydaje się, że w dziedzinie nauczania przedsiębiorczości w szkołach w Europie cały czas pozostaje wiele do zrobienia. Kształtowanie kompetencji kluczowej w warunkach szkolnych, w ramach przedmiotów obowiązkowych, nadal stwarza liczne problemy dydaktyczne i organizacyjne, a nawet prawne (np. możliwość zakładania firm szkolnych i zatrudniania w nich uczniów). Nauczanie przedsiębiorczości okazuje się trudniejsze niż tradycyjnych przedmiotów szkolnych, a włączenie przedsiębiorczości do grona kompetencji kluczowych było zapewne bardzo pomocne, lecz - jak się wydaje - niewystarczające.

Być może odpowiedzią na niekompatybilność i rozproszenie efektów kształcenia oraz trudności w zapewnieniu dostępu do doświadczenia praktycznego w dziedzinie przedsiębiorczości jest opracowanie odrębnej strategii krajowej koncentrującej się na tej dziedzinie. Powstanie i realizacja takiej strategii zapewniają bardziej spójne i kompleksowe podejście do nauczania przedsiębiorczości. Strategie przeważnie uwzględniają warunki konieczne do wdrażania nauczania przedsiębiorczości, w tym współpracę międzyresortową, tworzenie partnerstw, angażowanie otoczenia społecznego i biznesu, a także wdrażają pro- 
cedury monitorowania realizowanych działań. Odrębne strategie są realizowane głównie w Europie Północnej (Finlandia, Szwecja, Norwegia, Estonia) oraz w regionie Bałkanów Zachodnich.

Drugie źródło inspiracji to niewątpliwie inicjatywy podejmowane przez instytucje pozaszkolne. Można więc mówić o szerokim włączeniu się w kształtowanie kompetencji przedsiębiorczych u młodzieży przez różne podmioty, w tym instytucje rządowe, samorządowe i organizacje pozarządowe (Borowiec-Gabryś, Kilar, Rachwał 2018; Rachwał i in. 2018). Potrzeba takich działań dotyczy zarówno Polski, jak i większości krajów w Europie. Pozostaje więc brać przykład z ciekawych doświadczeń krajów, które te rozwiązania już u siebie realizują. 


\section{Bibliografia}

$\rightarrow$ Borowiec-Gabryś, M., Kilar, W., Rachwał, T. (2018), Przedsiębiorczość jako kompetencja przyszłości [w:] S.M. Kwiatkowski (red.), Kompetencje przyszłości, Warszawa: Fundacja Rozwoju Systemu Edukacji, s. 70-89.

$\rightarrow$ Education, Audiovisual and Culture Executive Agency, Eurydice (2012), Entrepreneurship Education at School in Europe. National Strategies, Curricula and Learning Outcomes, Bruksela: Europejskie Biuro Eurydice.

$\rightarrow$ Kilar, W., Kurek, S., Osuch, W., Świętek, A., Rachwał, T. (2016), Koncepcja oceny i kształtowania postaw przedsiębiorczych na podstawie narzędzi wypracowanych w ramach projektu RLG, „Przedsiębiorczość - Edukacja”, nr 12, s. 426-443.

$\rightarrow$ Kilar, W., Kurek, S., Osuch, W., Świętek, A., Rachwał, T. (2017), Developing Entrepreneurial Competencies of the RLG Project Participants - Applicability of Assessment Tools and Results of Pilot Studies, „Przedsiębiorczość - Edukacja”, nr 13, s. 314-329.

$\rightarrow$ Komisja Europejska/EACEA/Eurydice (2016), Entrepreneurship Education at School in Europe. (Nauczanie przedsiębiorczości w szkołach w Europie) Raport Eurydice, Luksemburg: Urząd Publikacji Unii Europejskiej, Bruksela/Warszawa: Europejskie Biuro Eurydice/Fundacja Rozwoju Systemu Edukacji.

$\rightarrow$ Makieła, Z., Rachwał, T. (2002), Podstawy przedsiębiorczości-poradnik metodyczny dla nauczycieli liceum ogólnokształcącego, liceum profilowanego i technikum, Warszawa: Wydawnictwo Nowa Era.

$\rightarrow$ Rachwał, T., Kilar, W., Kawecki, Z., Wróbel, P. (2018), Edukacja w zakresie przedsiębiorczości w wychowaniu przedszkolnym, szkole podstawowej i szkołach średnich w świetle nowej podstawy programowej, „Przedsiębiorczość - Edukacja", nr 14, s. 389-424.

$\rightarrow$ Rachwał, T., Kurek, S. Boguś, M. (2016), Entrepreneurship Education at Secondary Level in Transition Economies: A Case of Poland, „Entrepreneurial Business and Economics Review", nr 4 (1), s. 61-81. 
$\rightarrow$ Wach, K. (2013), Edukacja na rzecz przedsiębiorczości wobec współczesnych wyzwań cywilizacyjno-gospodarczych, „Przedsiębiorczość - Edukacja”, nr 9, s. 246-257. 


\section{Netografia}

$\rightarrow$ Fundacja Młodzieżowej Przedsiębiorczości, Młodzieżowe miniprzedsiębiorstwo - o programie, miniprzedsiebiorstwo.junior.org.pl (dostęp: 30.01.2019).

$\rightarrow$ Płatos, B. (2018), Przedsiębiorczość w praktyce: firma na terenie szkoły, eurydice.org.pl/wp-content/uploads/2018/11/firma.pdf (dostęp: 20.11.2018).

$\rightarrow$ Sawiński, J.P. (2011), Jak w szkole uczyć przedsiębiorczości? Portal edunews.pl, edunews.pl/badania-i-debaty/opinie/1648-jak-w-szkole-uczyc-przedsiebiorczosci (dostęp: 15.11.2018). 